水 文・水資源 学 会 誌

J. Japan Soc. Hydrol. \& Water Resour.

Vol. 16, No. 5(2003) pp. 491-500

\title{
都市接地層における熱・水蒸気・ $\mathrm{CO}_{2}$ の乱流輸送効率の相似性
}

\author{
Turbulent Transfer Efficiency of Heat, Vapor, and $\mathrm{CO}_{2}$ \\ Measured in an Urban Surface Layer
}

\author{
森脇 亮・神田 学* \\ Ryo MORIWAKI $\cdot$ Manabu KANDA \\ 菅原広史 ${ }^{* *}$
}

Hirofumi SUGAWARA

\author{
(東京工業大学大学院理工学研究科) \\ Graduate School of Science and Engineering, Tokyo Institute of Technology \\ (防衛大学地球海洋学科) \\ Dept. of Earth and Oceanic Science, National Defense Academy of Japan
}

\begin{abstract}
A long-term field measurement was performed to investigate turbulent transfer in a densely built-up urban surface layer. The turbulent transfer efficiencies of heat, vapor, and $\mathrm{CO}_{2}$ were examined. In the morning the low-frequency eddies penetrating the entire atmospheric boundary layer transfer water vapor efficiently due to the entrainment of dry air from upper to the surface. M.O.S. theory predicts that relative transfer efficiencies are unity and have no dependency on stability. But ratios for vapor/heat and $\mathrm{CO}_{2} /$ heat observed show that the transfer efficiencies of vapor and $\mathrm{CO}_{2}$ are smaller than heat. This tendency is more significant in unstable condition. In order to discuss this result, wavelet analysis for transfer efficiency of scalars was conducted. The thermal structure and organized structure transfer heat efficiently. Vapor and $\mathrm{CO}_{2}$ are also transferred as well as heat by some structures. But they are not or adversely transferred by other structures. Followings are considered as this reason. (1) Heat is an active scalar and produces the thermal structures by itself. Hence, the heat is transferred most efficiently. Vapor and $\mathrm{CO}_{2}$ are transferred passively and the efficiency is less than heat. (2) The absorption/source of vapor and $\mathrm{CO}_{2}$ is inhomogeneous. As a result, the heterogeneity of vapor and $\mathrm{CO}_{2}$ concentration distribution causes their transfer efficiency lower.
\end{abstract}

Key words: Urban surface layer, Turbulent transfer, Scalar, Field observation, Wavelet analysis

都市接地層内における熱・水蒸気・ $\mathrm{CO}_{2}$ 輸送を把握するため , 東京都大田区久が原の住宅地にて長期観測を行った . フラックス の相関係数を用いてスカラー間の輸送効率を調べたところ, 以下のことが明らかになった . 1)熱と水蒸気の輸送効率比は, 朝方大 きく日中にかけて小さくなる傾向がみられる . 朝方の不安定時は, 大きなスケールの渦構造によって混合層上端からの乾燥空気が 連行されることにより，熱に比べて水蒸気が効率的に輸送されると考えられる．2)日中の定常と見なせる時間帯において，スカ ラー間の相関係数を比較したところ, 熱・水蒸気・ $\mathrm{CO}_{2}$ の順で輸送効率が悪くなる. スペクトル解析・ウェーブレット解析を用い て輸送効率に寄与する渦スケールの特定を行った結果, サーマルやシアー不安定による組織渦が熱, 水蒸気, $\mathrm{CO}_{2}$ 光れ攵れの輸送 を担っている．しかし，これらの輸送イベントの各スカラー量に対する効果は同一ではない，弚の原因として，スカラー間の濃度 分布の不均一性に差異があること, 熱がアクティブなスカラー量であるのに対し水蒸気・ $\mathrm{CO}_{2}$ が受動的なスカラ一量であること，が 理由として挙げられる .

キーワード : 都市, 乱流輸送, スカラー, 現地観測, ウェーブレット解析

I .はじめに

1968年に行われたアメリカ・カンザス州での大規 模野外観測を代表に, 平原・森林・海上といった
フィールドで大気乱流による地表面一大気間の運動 量・熱・水蒸気の輸送過程に関する観測研究が数多 く行われ，接地層ではモニンーオブコフ相似則（以 下,MOST)が成立することが多くの研究で認められ

\footnotetext{
*東京工業大学大学院理工学研究科 $=152-8552$ 東京都目黑区大岡山 2-12-1

Graduate School of Science and Engineering, Tokyo Institute of Technology, Tokyo 152-8552, Japan

**防衛大学地球海洋学科

Dept. of Earth and Oceanic Science, National Defense Academy of Japan, Yokosuka 239-8686, Japan
} 
てきた .この相似則は, 運動量や熱だけでなく他の スカラー量にも拡張適用され，例えばOhtaki(1985) は $\mathrm{CO}_{2}$ の乱流統計量にもMOSTが認められると述べ ている．しかし我々の生活拠点である都市域におい てはMOSTの成立を保証するような観測例は少ない． Roth and Oke $(1993,1995)$ や神田ら (2000) は都 市における観測結果に基づき, 鉛直風速や温度や水 蒸気の相関係数に相似性が成り立たず, 平原と都市 では乱流輸送特性が一部異なる傾向を示すことを指 摘している.これらの観測は短期的なものであり一 般論として見なすには慎重を期する必要があるが， 接地境界層理論の根底に関わる極めて重要な指摘で ある、著者らは都市と大気間のエネルギー・物質輸 送を包括的に把握することを目的に, 東京都久が原 の住宅地において都市におけるフラックスの長期的 な観測を行っている. 夏季のデータの一部であるが 水文陸面パラメータや都市接地層の成立条件につい ては, 森脇ら (2002)，渡邊ら (2002) などですで に報告してきた . 本論は , 長期観測に基づき都市接 地層内のフラックス特性について述べるものであり， 第 1 報（森脇・神田，2002）でフラックスの季節変 化の特徵を示した．本報は第 2 報にあたり，スカ ラー間の乱流輸送の相似性について検討する . 数あ る相似則の中で特に重要なのが, 風速や温度などの 無次元勾配 (シアー関数) であるが, 光の前段階と して本研究では, Roth and Oke (1993) に従ってス カラー間の乱流相関係数に着目して議論する . また これまで都市では報告されていない $\mathrm{CO}_{2}$ の乱流輸送 の相似性についても検討した .

\section{II . 観測概要およびデータ処理方法}

\section{1. 観測場所および測定方法}

東京都大田区久が原の住宅地上空において2001年 5 月より継続的な乱流計測が行われている . タワー 周辺の住宅地は $1 \mathrm{~km}$ 四方に渡り第一種低層住宅専 用地域に指定されており建物の殁どが 2 階建の住宅 である．建蔽率は約47\%であり欧米諸国に比べて密 な住宅街といえる、建物高さ測量の結果，建物高さ の平均値は7 3m, 標準偏差は1 3m であり住宅街は ほぼ一樣な高さの建物で構成されている．観測場所 の詳細については, 森脇・神田 (2003) を参照され たい. 都市における運動量粗度 $\left(z_{0}\right)$ およびゼ口面 変位 $\left(z_{d}\right)$ には数多くの算出法が提案されているが (Grimmond and Oke, (1999) に詳しい), 本研究で は比較的広範な幾何条件に適用できる式として彼ら
表 - 1 都市の幾何パラメータ

Table 1 Geometric parameters of the site

\begin{tabular}{llll}
\hline \hline 建物高さ & $z_{\mathrm{H}}$ & 平均 & $7.3 \mathrm{~m}$ \\
\cline { 3 - 4 } & & 標準偏差 & $1.3 \mathrm{~m}$ \\
\hline 建蔽率 & $\lambda_{\mathrm{p}}$ & & $47.4 \%$ \\
\hline $\begin{array}{l}\text { フロンタルエリア } \\
\text { インデックス }\end{array}$ & $\lambda_{\mathrm{f}}$ & & $52.0 \%$ \\
\hline 緑被率 & & \\
\hline 運動量粗度 & & $22.0 \%$ \\
\hline ゼロ面変位 & $\mathrm{z}_{0}$ & $0.58 \mathrm{~m}$ \\
\hline \hline
\end{tabular}

が推奨している Macdonald et al. (1998) の定式化を 用いることにする．

$$
\begin{aligned}
& \frac{z_{d}}{z_{h}}=1+4.43^{\lambda_{p}}\left(\lambda_{p}-1\right) \\
& \frac{z_{0}}{z_{h}}=\left(1-\frac{z_{d}}{z_{h}}\right) \exp \left\{-\left[0.5 \frac{c_{d}}{k^{2}}\left(1-\frac{z_{d}}{z_{h}}\right) \lambda_{f}\right]^{-0.5}\right\}
\end{aligned}
$$

ここで, $z_{h}$ は建物高さ, $c_{d}$ は抵抗係数1 $2, k$ はカル マン定数O $4 \lambda_{p}$ は屋根・敷地面積比 (建蔽率) $\lambda_{f}$ は鉛直壁・敷地積比である.都市の幾何パラメータ と $z_{0} \cdot z_{d}$ をまとめて表 -1 に示す .

本研究では都市の接地境界層内での計測を行うた め, 高度29 .0m（建物高さの約 4 倍, タワー頂上 部）に計測機器を設置した .この高さに内部境界層 が発達するには, 性状の変わらない住宅街が数百〜 $1 \mathrm{~km}$ に渡って広がっていることが必要である . 本 研究で観測対象としているエリアはこの条件を満た している . 本観測における測定高度の決定方法や接 地境界層の成立性の詳細については渡邊ら (2002) を参照されたい，観測に使用したタワーはトラス式 構造の自立型タワーであり充実率 (水平風速に対す る部材の射影面積比) は0 27である.タワーによる 気流の乱れの影響を排除するため, タワーと乱流計 測機器の距離はタワー幅の1 5倍とした . 三次元超 音波風速温度計 (Metek 社; USA-1) とオープンパ ス $\mathrm{CO}_{2} / \mathrm{H}_{2} \mathrm{O}$ アナライザー (Li-cor 社; LI-7500) を用 いて, 3 次元風速 $\cdot$ 気温 $\cdot \mathrm{CO}_{2}$ 濃度 ·水蒸気濃度の 瞬間值を $8 \mathrm{~Hz}$ のサンプリング周期で計測した .

\section{2 . データ解析手法}

フラックスの算出には渦相関法を用いた . フラッ クス算出の乱流統計時間は60分とした . バイアス除 去のため McMillen (1988) に倣い, 平均横断風速 $\bar{v}$ $=0$, 平均鉛直風速 $\bar{w}=0, \overline{v^{\prime} w^{\prime}}=0$ となるよう風速 の座標変換を行った . 潜熱・ $\mathrm{CO}_{2}$ フラックスに対し 
てはWebb et al. (1980) の密度変動補正を加えた .

本稿ではスカラー間の鉛直輸送効率について議論 する . 以下に示す乱流相関係数はスカラー量の鉛直 輸送効率を表すパラメータであり，0（相関無し） から 1 (最も効率良く輸送) の值をとる.

$$
\begin{aligned}
& r_{w T}=\left|\overline{w^{\prime} T^{\prime}}\right| / \sigma_{w} \sigma_{T} \\
& r_{w q}=\left|\overline{w^{\prime} q^{\prime}}\right| / \sigma_{w} \sigma_{q} \\
& r_{w c}=\left|\overline{w^{\prime} c^{\prime}}\right| / \sigma_{w} \sigma_{c}
\end{aligned}
$$

ここでは $w$ 風速の鉛直方向成分を表し， $T$ は気温， $q$ は比湿, $c$ は $\mathrm{CO}_{2}$ 濃度を表す . $\sigma$ は標準偏差であ る . プライムは時間平均值(上付きバーで表される) からの瞬間的な偏差である .これら乱流相関係数の 比をとることで，スカラー間の相対的な輸送効率を 調べることができる．

\section{3 . 解析に使用したデータ}

本論では2001年 5 月 1 日 12月31日までのデータ を使用した . データの品質を高めるために下記のよ うな基準を設けた . (1)日照率が80\%を超える晴天日 のデータのみを使用する . 晴天日の決定方法や日数 については，森脇・神田 (2003) を参照されたい． (2)統計的な不安定を避けるため, 表 - 2のように光 れ光れのフラックスに下限值を設定し, フラックス の絶対值がこれより小さいデータは除去した . (3)モ ニン一オブコフ相似則 (MOST) は定常な気象条件 時に適用できる，乥のため，MOST の成立性を議論 するIII章 2 節では, 日射量, 気温, 比湿, 風速の変 化率が小さく定常と見なせる日中の11時から14時の データに限って解析を行った .

\section{III. 乱流相関係数}

1. 熱と水蒸気の輸送効率比の時間変化パターン MOST の枠組で議論を行うためには気象場が定常 であることが条件となる．しかし気象場が定常であ る時間帯は一日の中でも数時間しか存在せず, 光の 他の時間帯を含めたスカラー輸送特性を知ることも 極めて重要である . 弚こでスカラー間の輸送効率比 の時間変化挙動を追ったところ興味深い傾向が見出

表- 2 フラックスの下限值

Table 2 Lower limits of fluxes

\begin{tabular}{lc}
\hline 運動量フラックス & $0.05\left(\mathrm{kgm}^{-1} \mathrm{~s}^{-2}\right)$ \\
顕熱 & $30\left(\mathrm{Wm}^{-2}\right)$ \\
潜熱 & $30\left(\mathrm{Wm}^{-2}\right)$ \\
$\mathrm{CO}_{2}$ フラックス & $0.02\left(\mathrm{mgm}^{-2} \mathrm{~s}^{-1}\right)$ \\
\hline
\end{tabular}
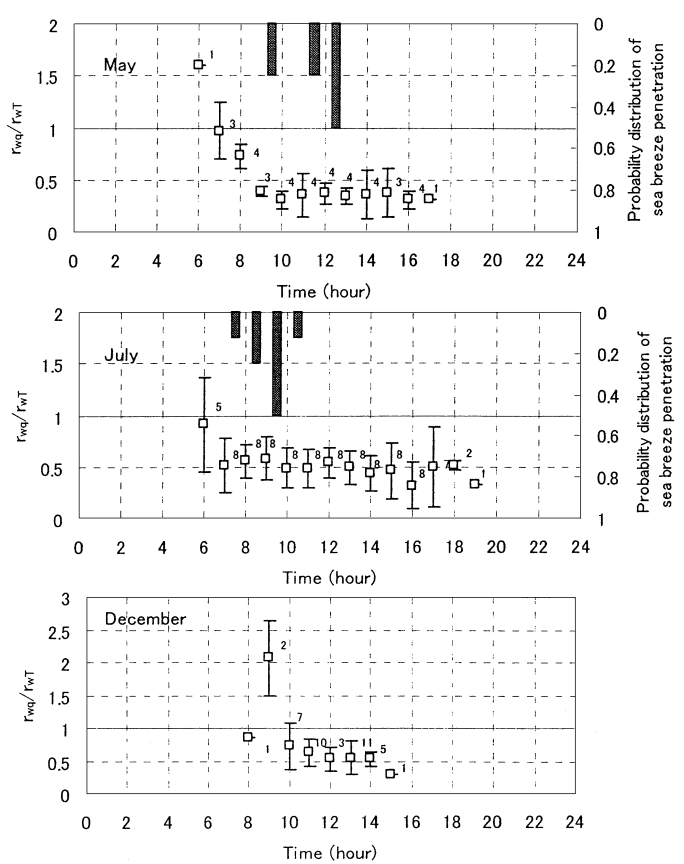

図-1 5 月・ 7 月·12月の晴天日における,$r_{w q} / r_{w T}$ の時間変化パターン. 図中の棒グラフは海風侵入 時刻の確率分布

Fig. 1 Diurnal change of $r_{w q} / r_{w T}$ in May (top), July (middle) and December (bottom). A bar graph indicates the probability distribution of sea breeze penetration

せたので, ここでは熱と水蒸気の輸送効率比 $\left(r_{w q} / r_{w T}\right)$ の時間変化を例に挙げて議論する.

図 - 1 に 5 月・ 7 月・12月の晴天日における， $r_{w q} / r_{w T}$ の時間変化挙動のアンサンブル平均を示す . プロットで平均值を表し, 誤差バーで標準偏差を表 した . また各プロットには平均データ個数を数字で 示している. 朝方と夕刻にデータが少ないのはフ ラックスの下限値設定によってデータが除去されて いるためである $. r_{w q} / r_{w T}$ は朝方に大きくなる傾向が 見て取れ，兴の值は 1 と同等か关れより大きくなる． つまり朝方は水蒸気の輸送効率が良くなるという興 味深い結果が得られている. 一方 MOSTが仮定でき る気象場の定常な正午付近の值でも輸送効率比は 1 にならず0 5程度である.つまり水蒸気の輸送効率 が熱に対して小さくなっていることを意味する . 定 常時に $r_{w q} / r_{w T}$ が1にならないことについては次節で 詳しく検討し, ここでは $r_{w q} / r_{w T}$ の時間変化の特徵に 着目し, 熱と水蒸気の輸送効率比 $r_{w q} / r_{w T}$ が朝方に大 
きく日中になると小さくなる理由について検討する .

気温や比湿は1日の中で時間変化する. 光のため， トレンドとして捉えられる気温や比湿の日変化が。 (標準偏差) を大きくする可能性があり，これが $r_{w q} / r_{w T}$ の時間変化に影響している可能性がある.し かし, 各データセットに対しトレンドを線形除去し ても $r_{w q} / r_{w T}$ の時間変化の特徵は変わらない. 乥こで 次に, 接地層におけるスカラー量の輸送効率を大き く変化させる要因として,1)海風の侵入, 2)混合層 上部との交換過程, の可能性について検討する . ま ず第一に海風の侵入との関係について考察する . 海 風のフロントが通過するようなイベントでは, 混合 層内の風速や気温や比湿の分布が大きく変化し, 接 地層におけるスカラー輸送に影響を与えることは可 能性として十分に考えられる. 図中に棒グラフで示 したのは海風侵入時刻の確率分布である. 春季 ( 5 月) も夏季 ( 7 月) も南からの海風の侵入は明確で あり，侵入時刻は 5 月は10時〜13時ころ， 7 月は 8 ～11時ころに集中している. しかし $r_{w q} / r_{w T}$ は朝 6 ～ 8 時ころにはすでに大きく変化しており, 海風の侵 入時刻に先だっている.一方12月は北寄りの風が卓 越し日中の海風の侵入は明確でないにも関わらず， $r_{w q} / r_{w T}$ には変化が認められる. 乥こで次に2)混合層 上部との交換過程，の影響について検討する . 図 2 に夏季における混合層高度の時間変化パターンを 示す. 各時刻の混合層高度はライダーを用いて後方 散乱強度の鉛直分布より推定した . 結果は2002年の 夏季に東京工業大学屋上 (フラックス観測地点との 距離は $3 \mathrm{~km}$ ) で測定されたデータのうち，晴天日の

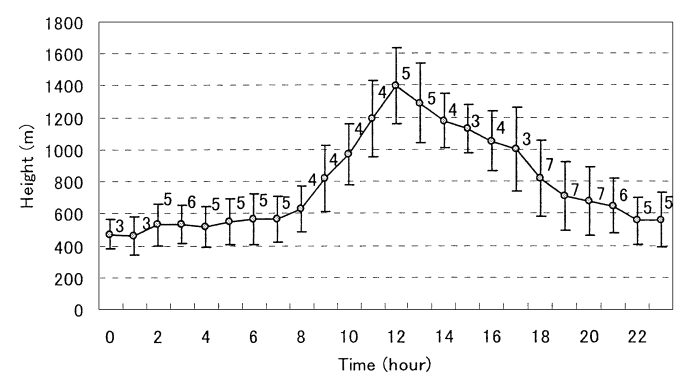

図 - 2 夏季の混合層高さの時間変化パターン (2002年 8 月 6 日〜 9 月 2 日までの晴天日のアン サンブル平均)

Fig. 2 Diurnal change of mixing layer height, ensemble averaged over clear days

from Aug. 6 to Sep. 2 in 2002
データをアンサンブル平均したものである . プロッ 卜で平均值を示し，誤差バーで標準偏差を示してい る.プロットの右肩の数字は平均したデータ個数で ある.混合層高度は朝方に低く光の高さは400〜 $600 \mathrm{~m}$ 程度である.日中は急激に発達して1200〜 $1600 \mathrm{~m}$ の高度に達する . 兴の後夜間にかけて高度は 緩やかに低下する $. r_{w q} / r_{w T}$ の時間変化はこの混合層 の変化と対応しているのではないだろうか $. r_{w q} / r_{w T}$ が大きい朝方の時間帯は風速が弱く大気が不安定な 状態となる傾向がある. 朝方に混合層が発達し始め る段階では, 混合層上部でエントレイメントの作用 により取り込まれた上層の乾燥した空気塊が地表付 近まで運ばれ結果的に接地層での水蒸気の輸送効率 が良くなると推測される . また混合層が発達するに つれて, 接地層での輸送に対する混合層上との交換 過程の影響は弱まり, 水蒸気の輸送効率は低下して いく. 弚こで $r_{w q} / r_{w T}$ の挙動が典型的である 7 月11日 に注目し $\left(r_{w q} / r_{w T}\right.$, 風速, 大気安定度 $z^{\prime} / L$ の時間変 化を図 - 3 に示す), 大気が不安定な朝方 $7 \sim 8$ 時 の $w^{\prime} T^{\prime} / \sigma_{w} \sigma_{T}, w^{\prime} T^{\prime} / \sigma_{w} \sigma_{T}, w^{\prime} \sigma_{w}, T^{\prime} \sigma_{T}, q^{\prime} \sigma_{q}$ の 時系列データに対して時間一周波数解析の一つであ るウェーブレット解析を行った . ウェーブレット解

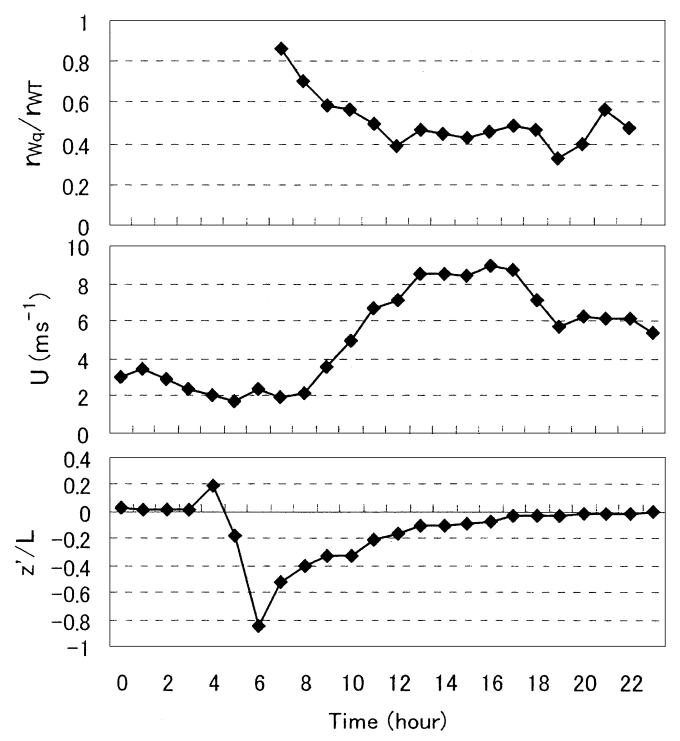

図 - 3 2001年 7 月11日における $r_{w q} / r_{w T}$ (上) と主 流平均風速 (中) と大気安定度 (下) の時間变化

Fig. 3 Diurnal change of $r_{w q} / r_{w T}$ (top), horizontal wind speed (middle) and atmospheric stability (bottom) on Jul. 11 in 2001 


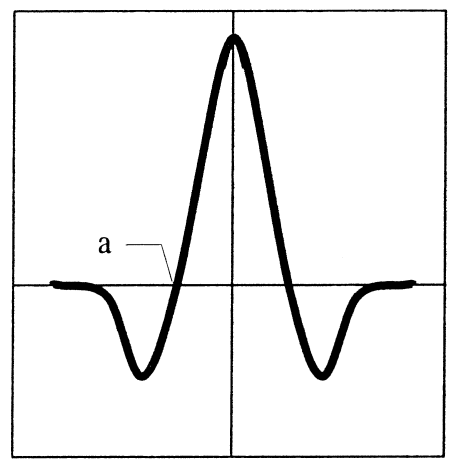

図 - 4 解析に用いたマザーウェーブレット（ a は タイムスケール)

Fig. 4 Analyzing wavelet function. a indicates time scale of the wavelet

析によって熱および水蒸気の輸送に寄与している乱 流渦のスケールと光の発生時刻が容易に把握出来る . マザーウェーブレットには図 - 4 に示すようなメキ シカン・ハット (ガウス確率密度関数の 2 階導関数) を用いた .メキシカンハット関数は時間においても 周波数においてもよく局在化されている利点があり， 大気乱流の研究にもよく用いられている(例えば， Gao and Li，(1993)) . 図－5にウェーブレット解析 結果を示す . 縦軸はマザーウェーブレットのタイム スケール (図 - 4中のa) であり, 存在する渦のス ケールと解釈されたい，また横軸は時間軸である． マザーウェーブレットとの正の相関が強い部分を黑, 負の相関が強い部分を白でコンターを書いた . (a)中 で破線で囲った部分は，時間スケール a が $64 \mathrm{sec}$ $128 \mathrm{sec}$ であること, 上昇気流が起きていて気温も 上昇していること (図(c), (d)参照), から判断して サーマルによる上向きの熱輸送が生じていると考え られる．熱はサーマルによって効率良く輸送が行わ れているが, 水蒸気はサーマルによって輸送が行わ れたり，行われなかったりする．この原因についは $\mathrm{IV}$ 章で詳細に検討する．ここで注目したいのは，実 線で囲った部分 ( $7: 50$ ～ 8 : 00頃) である.この スケールはサーマルとほぼ同等であるが, この構造 では熱は全く輸送されず水蒸気のみ輸送が効率良く 行われている.(c)を見るとこの構造では下降流が生 じており，このとき温度は上昇，比湿は低下してい る .このことからサーマルとは異なる現象によりス カラー輸送が生じていると考えられる .この構造が 朝方のみに見られること, スケールの大きい構造で

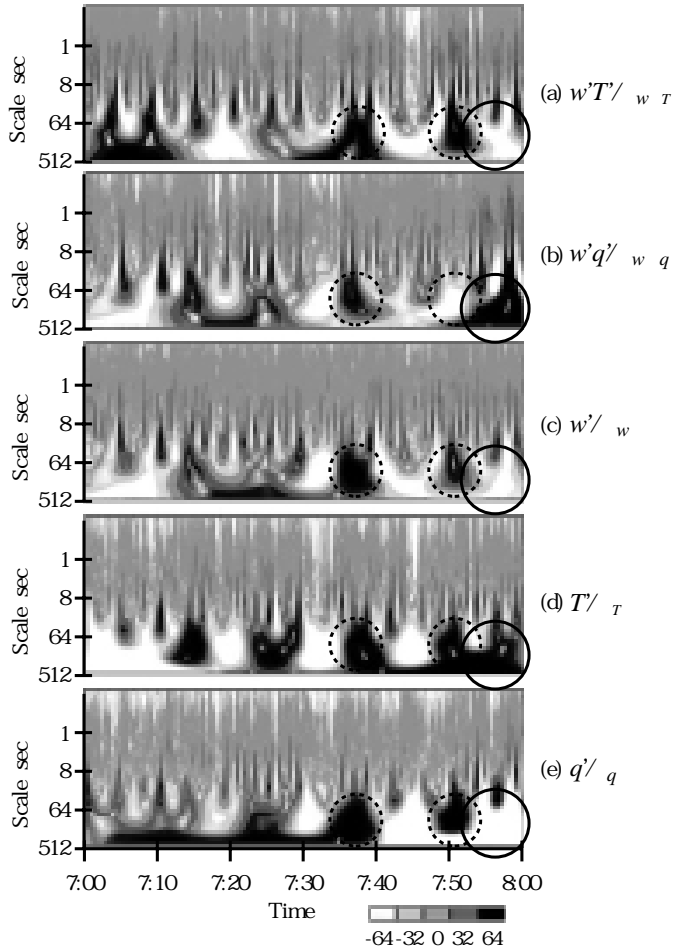

図 - 5 (a) $w^{\prime} T^{\prime} \boldsymbol{\sigma}_{n} \boldsymbol{\sigma}_{T}$, (b) $w^{\prime} q^{\prime} \boldsymbol{\sigma}_{w} \boldsymbol{\sigma}_{q}$, (c) $w^{\prime} \boldsymbol{\sigma}_{w}$, (d) $T^{\prime} / \sigma_{T}$, (e) $q / \sigma_{q}$ に対するウェーブレット係数のコ ンター図.7月11日 7:00〜8:00

Fig. 5 Contours of wavelet coefficients for (a) $w$ 'T'/ $\boldsymbol{\sigma}_{w} \boldsymbol{\sigma}_{T}$, (b) $w^{\prime} q^{\prime} \boldsymbol{\sigma}_{w} \boldsymbol{\sigma}_{q}$, (c) $w^{\prime} \boldsymbol{\sigma}_{w}$, (d) $T^{\prime} / \sigma_{T}$, (e) $q^{\prime} / \sigma_{q}$ from 7:00 to 8:00 on Jul. 11 in 2001.

あることの 2 点から, 境界層スケールの大きな渦が 混合層が急激に発達する過程において上空の乾燥し た空気を取り込んでいると考えられる. 光の結果， この空気と地表面付近の相対的に湿潤な空気の交換 が行われ，水蒸気の輸送効率が高くなると考えられ る.夕刻, 混合層高度はゆっくりと低下しながら残 留層へと推移する . 残留層の存在により上層大気と 地表の間には水蒸気の交換が生じにくいと考えられ る.

2 . スカラー間の輸送効率比と大気安定度の関係 前節より乱流相関係数は 1 日の混合層変化に対応 しており，弚の原因として混合層上空気塊との交換 過程について議論した. 本来, MOST は気象条件が 定常的であることを前提にしているので，本節では 


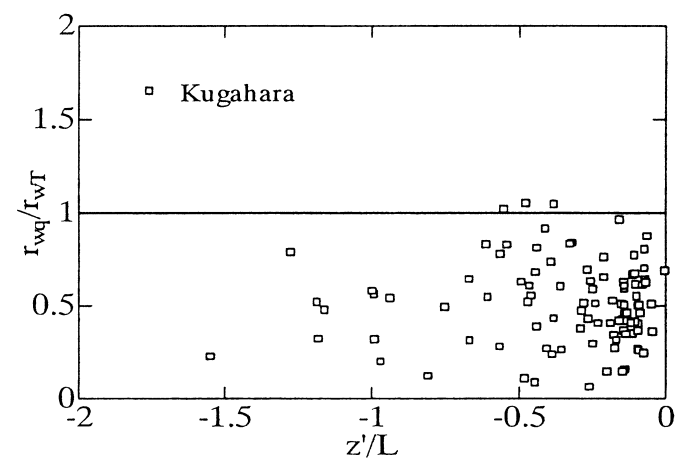

图 - 6 水蒸気の熱に対する鉛直輸送効率比

Fig. 6 Relative efficiencies of turbulent transfer of vapor to heat $\left(r_{w q} / r_{w T}\right)$ versus atmospheric stability

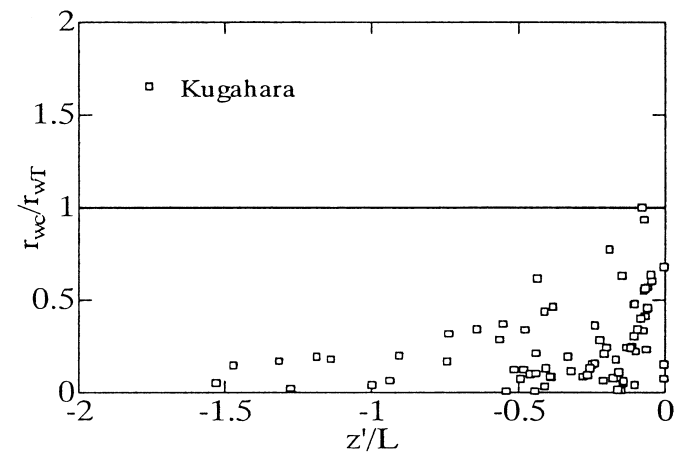

図 - 7 二酸化炭素の熱に対する鉛直輸送効率比

Fig. 7 Relative efficiencies of turbulent transfer of

$\mathrm{CO}_{2}$ to heat $\left(r_{w c} / r_{w T}\right)$ versus atmospheric stability

日中の定常と見なせる時間帯 (11時から14時) にの みデータを絞り，スカラー間の輸送効率比と大気安 定度との関係について検討した．

図 - 6 に大気安定度に対する水蒸気と熱, 図 - 7 に $\mathrm{CO}_{2}$ と熱の相関係数の比を示す . MOST によると スカラー量は大気安定度によらず全て同等に輸送さ れるとされているため, スカラー間の輸送効率比は 1 になることが期待される.しかし測定結果は1を 下回り，熱に比べて水蒸気, $\mathrm{CO}_{2}$ の順で相関係数 (輸送効率) が小さくなる傾向が見られた．Roth and Oke (1993) もバンクーバーの住宅街上の観測 結果をもとに, 水蒸気と熱の輸送効率比は1になら ないことを指摘しており, 光の原因として，(1)発生 源の不均一性，(2)放射に対する雲の効果，(3)逆転層 上大気とのインタラクション，などを挙げている． 本研究では, 混合層が十分に発達している晴天日の
昼間のデータのみを使用しているため雲の影響や上 層大気とのインタラクションが起きているとは考え にくい.ここではソースの不均一性について考察す る.日中太陽に加熱される都市 (家屋, 道路, 庭木 など）は熱に対して均一な発生源として取り扱って よいと考えられる(神田ら，2000).一方森脇・神 田 (2003) は水蒸気や $\mathrm{CO}_{2}$ の発生源について詳細に 調べており，水蒸気に対しては庭木が発生源に， $\mathrm{CO}_{2}$ に対しては家庭・自動車交通が発生源，庭木は 逆に吸収源になっているとしている.このように考 えると, フラックスの大きさに対する発生源の不均 一性は, 熱よりも水蒸気の方が大きく，水蒸気より も $\mathrm{CO}_{2}$ の方が大きくなる . この発生源の不均一性の ため, 水蒸気や $\mathrm{CO}_{2}$ の濃度分布にも空間的なむらが 生じやすく, フラックスに寄与しない $\sigma_{q} や \sigma_{c}$ が増 大したために, 水蒸気や $\mathrm{CO}_{2}$ の相関係数が熱に比へ て小さくなったと考えられる．水蒸気の場合は顕著 ではないが, 特に $\mathrm{CO}_{2}$ の場合, 大気が不安定になる につれて輸送効率比が小さくなるのは不安定時に熱 か効率よく輸送されやすくなるためと考えられるが， 詳細な輸送メカニズムについては次章にて検討する．

IV . 乱流輸送のメカニズム

1 . スカラー輸送に支配的な乱流構造

7 月11日 $\left(r_{w q} / r_{w T}\right.$, 風速, $z^{\prime} / L$ の時間変化は図 -3 参照) の13時における, 熱・水蒸気・ $\mathrm{CO}_{2}$ フラック スのコスペクトルを図 - 8に示す .コスペクトルは 弚れ光れ鉛直風速とスカラー量の標準偏差で規格化 し , 周波数で重み付けしている . スカラーフラック スのコスペクトルには共通したピークが認められ (図中に示したハッチング), 各スカラー量はある共 通した乱流構造によって主に輸送されていると考え られる . 図中に示した矢印と番号に対応する乱流構

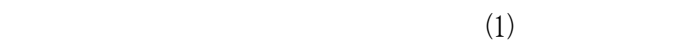
による組織渦，(2)熱対流 (サーマル) であると考え られ，以下光れ光れ検討する．

1 ) 組織渦

境界層における不安定時の $w^{\prime} T^{\prime}$ のコスペクトル のピークは測定高度 $\left(z-z_{d}\right)$ に比例することが知ら れている (Kaimal and Finnigan, 1994). 本観測高度 $(z=29 \mathrm{~m})$ とゼロ面変位 $\left(z_{d}=5.3 \mathrm{~m}\right)$ からコスペク トルピークの波長を計算すると, 渦の水平スケール $\lambda_{m}$ は約300m となる.この時間帯の風速は8 $5 \mathrm{~m} \mathrm{~s}^{-1}$ であるので周波数に換算すると0 $029 \mathrm{~Hz}$ となる . 観 測されたコスペクトルのピーク (図 - 8に示した 


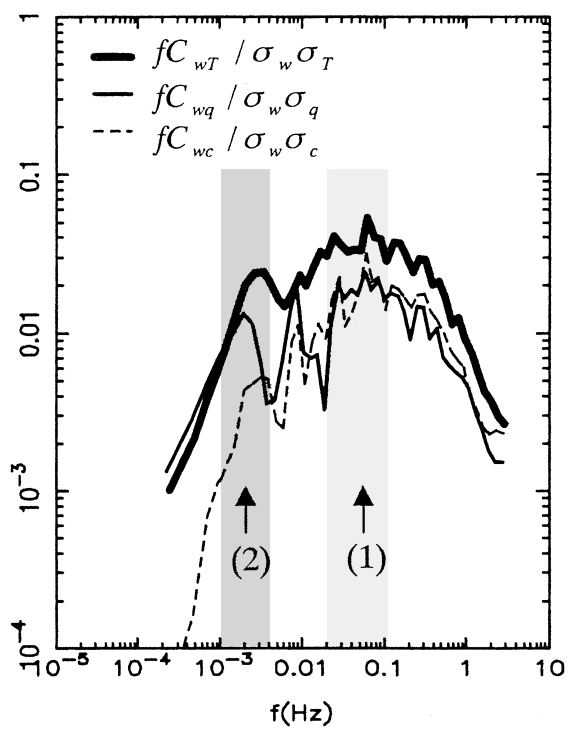

図－8 スカラー輸送の規格化コスペクトル . 2001 年 7 月11日 $(13: 00 \sim 14: 00)$

Fig. 8 Normalized co-spectrum of heat, vapor and $\mathrm{CO}_{2}$ from 13:00 to 14:00 on Jul. 11 in 2001.

ハッチング) はこの周波数を含むが，より高周波側 (0 .03〜0 1Hz) にも強いピークが見られる.つまり 接地層理論で得られるスペクトルピークよりもやや 高周波側にピークか推移している．植生キャノピー 内と关の近傍では, 抵抗体 (草や樹木) の存在に よって風速分布に変曲点が存在し, シアー不安定に よる組織構造か活乚れを支配していることが知られて いる(例えば , Kanda and Hino, 1994; Raupach et al., 1996). Ho and Huerre (1984) によると, 流速分布 に変曲点を有するせん断流れにおいて発生する渦の 最大発達率を示す周波数 $f$ は,

$$
\frac{\theta}{U_{m}}=0.032
$$

で与えられる .ここに 運動量欠損を $U_{\infty}^{2}$ で割った運動量厚さ， $U_{\infty}$ はキャノ ピー上で流速がほぼ一定となる値 , $U_{m}$ はせん断層上 における流速の平均值である， $\theta$ にゼ口面変位 $z_{d}=$ $53 \mathrm{~m}$ (表-1) を与え， $U_{m}$ に高度 $29 \mathrm{~m}$ で測定され た風速 $8.5 \mathrm{~m} \mathrm{~s}^{-1}$ を与えたところ， $f$ は約 $0.05 \mathrm{~Hz}$ と なった、上述した高周波側にピークが推移している 理由は，この組織渦の影響によると考えられる.植 生キャノピーの場合, 組織渦の影響範囲はキャノ ピー高さの 2 倍程度までと言われているが (Raupach et al., 1996) ，本観測ではキャノピー高さの 4
倍の高さにおいてもコスペクトルの周波数特性に組 織渦の影響が認められた．弚の理由の一つに本観測 場所が都市の上空であることが挙げられる . 植生と 都市のキャノピー構造には抵抗体の透過性に大きな 相違点がある . 都市では建物の背後にキャノピース ケールの後流が形成される . この後流と組織渦の相 互作用が, 弚の影響範囲を大きくしているのかもし れない、都市における乱流データを整理した Roth (2000) は都市キャノピー近傍において乱れの組織 構造のスケールが植生に比べて大きくなることを指 摘しており, 本結果と合わせて興味深い .この周波 数帯の水蒸気および $\mathrm{CO}_{2}$ のスペクトル強度は, 熱の スペクトル強度の約 $50 \%$ 程度である .これは前章で 述べたようにフラックスに寄与しない濃度変動（標 準偏差) が大きいためだと考えられる .

\section{2 ) サーマル}

実験室内の熱対流のアスペクト比（縦に対する横 の比) は約 1 であるが, 実際の大気中に存在する熱 対流はこれよりも大きくなることか数値計算によっ て確かめられている(神田，1994). 図-2より日中 の混合層高さは1500m であり, アスペクト比を1〜 5 程度であるとすると, サーマルの水平スケールは 1500〜 7500m に達すると考えられる .この時間帯の 平均風速は8 $5 \mathrm{~m} \mathrm{~s}^{-1}$ なので, サーマルの周期は200 〜900秒程度 (1 1 5 3 $\left.3 \times 10^{-3} \mathrm{~Hz}\right)$ となる.この乱 流構造は全てのフラックスにスペクトルピークとし て確認でき，サーマルがフラックスに寄与している ことがわかる . 各スカラー間でその強度を比較する と，水蒸気は熱の約 $50 \%, \mathrm{CO}_{2}$ は熱の約20\%である． 熱はアクティブなスカラーであるため, 熱自体が作 り出すサーマルでは熱は効率よく輸送される．しか し $\mathrm{CO}_{2}$ は濃度の空間的非一樣性が大きいためサーマ ルによる輸送効率が著しく低下すると考えられる． 図 - 7 において大気が不安定になるほど $r_{w c} / r_{w T}$ が小 さくなるのはこの理由によると思われる . 一方 , 水 蒸気は熱の50\%程度で $\mathrm{CO}_{2}$ のスペクトル強度より大 きい .この理由ははっきりしないが, サーマル程度 の大きいスケールでは, $\mathrm{CO}_{2}$ と比べて水蒸気の濃度 分布は一樣である（より熱に近い）とみなせ, サー マルによって輸送されやすいためかもしれない，次 節ではウェーブレット解析を用いてさらに詳しく検 討する . 

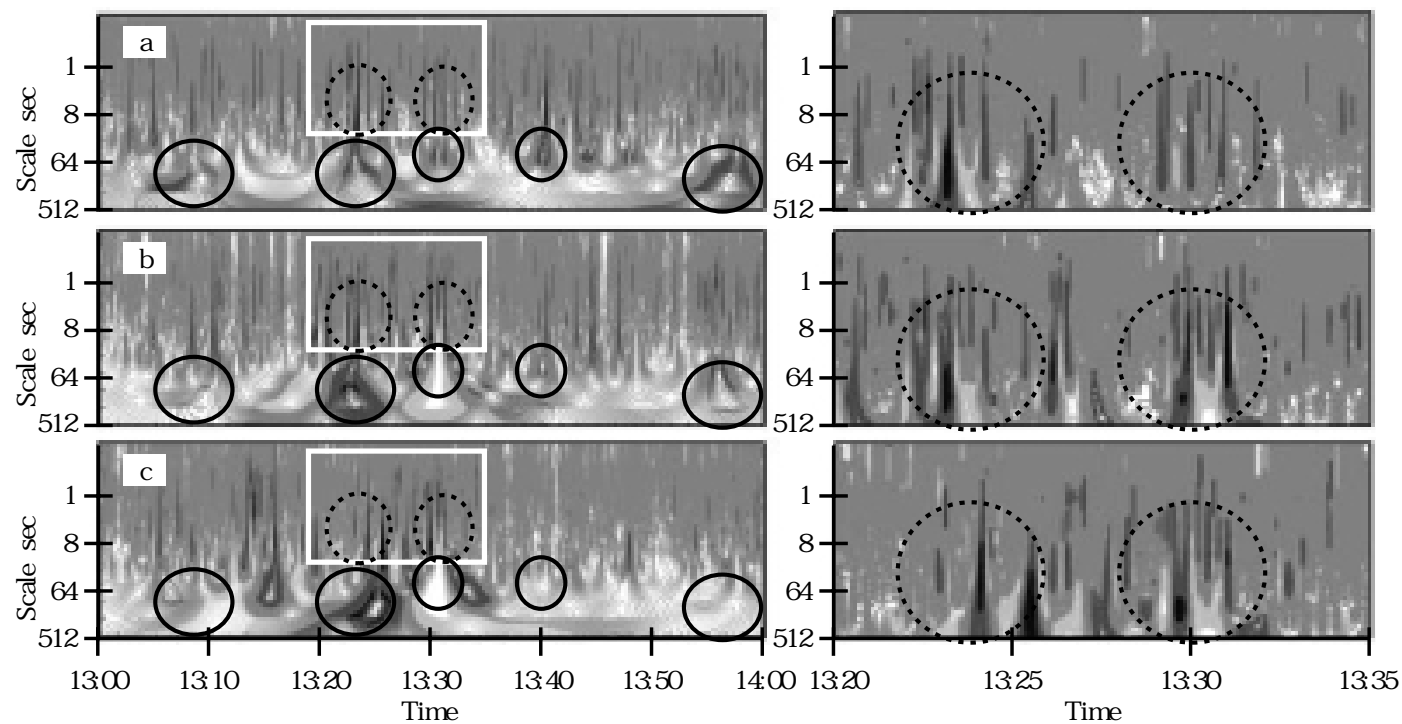

図 - 9 ウェーブレット係数のコンター図 . (a) $w^{\prime} T^{\prime} \boldsymbol{\sigma}_{w} \sigma_{T}$, (b) $w^{\prime} q^{\prime} \boldsymbol{\sigma}_{w} \sigma_{q}$, (c) $w^{\prime} c^{\prime} \boldsymbol{\sigma}_{w} \sigma_{c}$. 左図 : 2001年 7 月11 日 (13:00〜14:00), 右図 : 左図中の白四角の拡大図 . 図中，実線で囲んだ円がサーマルを，破線で囲ん だ円が組織渦を示す。

Fig. 9 Contours of wavelet coefficients for $w^{\prime} T{ }^{\prime} \boldsymbol{\sigma}_{w} \sigma_{T}$ (top), $w^{\prime} q^{\prime} \boldsymbol{\sigma}_{w} \sigma_{q}$ (middle), $w^{\prime} c^{\prime} \boldsymbol{\sigma}_{w} \sigma_{c}$ (bottom). Left figures: from 13:00 to 14:00 on Jul. 11 in 2001. Right figures: from 13:20 to 13:35 on Jul. 11 in 2001

2 .ウェーブレット解析によるスカラー間の輸送効 率の相違性

スカラー間の輸送効率の差異をさらに詳細に検討 するため前章同樣ウェーブレット解析を行った . 解 析例として 7 月11日13:00〜14:00の熱, 水蒸気， $\mathrm{CO}_{2}$ の輸送効率に対するウェーブレット係数のコン ターを図 - 9 に示す . 縦軸の時間スケールは図 - 4 に示したメキシカンハット関数のスケールである . 図左側の白四角で囲った部分の拡大図を図右側に表 示している . マザーウェーブレットのフーリエ変換 はある範囲をもつた周波数帯にパワーが存在するた め，一般にウェーブレットの時間スケールをフーリ 工変換における波数に厳密には置き換えられない (詳細は Perrier et al., 1995) が , メキシカンハット 関数の場合は $a=1 / 4 f$ でほぼ置き換えることができ る $. a<1$ ではウェーブレット係数が大きくなるよ うな構造はみられず，このような小スケールではフ ラックスの生成に寄与するような乱流構造は起きて いない.一方， $a>64$ の大きい構造 (図中で実線で 囲った部分) は前節で述べたサーマルに対応してい ると考えられる.サーマルは規則的ではなく間欠的
に生じている樣子がわかる . またこれら中間的なス ケール $(2<a<16)$ に存在する破線で囲った乱流 構造は組織渦に相当していると考えられる .この結 果では, 朝方に目立っていたサーマルによるスカ ラー輸送 (図 -5 の相関の高い部分) の強度は相対 的に弱くなっている.これは無次元化に用いた標準 偏差 $\left(\sigma_{w}, \sigma_{T}\right.$ など $)$ が日中に大きくなることが一因 だが, 風速の弱 強に対応している. 朝方は混合層 の発達とともに境界層厚さスケールのサーマルがス カラー量の輸送を担っているが, 日中に風が強まる とシアーによる比較的小さなスケールの組織渦がス カラー輸送を支配する . 組織渦によるスカラー量の 輸送は, サーマルによる輸送が起きている時間帯に 一致しており，大きな乱流構造 (サーマル) が小さ な乱流構造 (組織渦) のトリガーになっているよう にも見える . 同樣の結果は Gao and Li (1993) によ る森林内外の気温変動に対するウェーブレット解析 にも認められている .

図－9左を見ると，熱はサーマルによって常に効 率良く鉛直上向きに輸送されている(実線によって 囲まれた部分).一方，水蒸気や $\mathrm{CO}_{2}$ には，熱と同 
樣に輸送されるイベントもあれば，輸送されなかっ たり逆に輸送されたりするイベントがある．前章で も述べたように都市においては水蒸気や $\mathrm{CO}_{2}$ の主な 発生・吸収源は, 家屋や庭木や自動車交通などであ り，光の強度もスカラ一量によって異なる（森脇・ 神田，2003) ため，スカラー濃度分布にも空間的な むらが生じやすくなり，光の不均一性は，熱く水蒸 気 $<\mathrm{CO}_{2}$ の順となる. 熱は乥れ自体か輸送を生み出 すアクティブスカラー量であるため, サーマルが生 じる際に効率よく輸送されるが, 水蒸気や $\mathrm{CO}_{2}$ は受 動的に輸送されるパッシブスカラー量であるため， サーマル発生時に熱と同樣に効率よく輸送される事 もあれば輸送されないイベントもある，弚のため前 節でも議論したように，熱>水蒸気 > $\mathrm{CO}_{2}$ の順で輸 送効率が低下していくのだと考えられる . 一方, 組 織構造 (図 - 9右) においてもスカラ一輸送の相似 性は維持されておらず, 熱, 水蒸気, $\mathrm{CO}_{2}$ が同じよ うに輸送される場合もあれば, 全く異なる場合もあ る(図中の波線部分を比較されたい). 組織渦の場合 は熱は乱れの駆動力とはならないが, 前述したスカ ラー濃度分布の不均一性の差異によって , このス ケールの渦構造においても熱の輸送効率がよいとい う結果になったと考えられる。

\section{V .まとめ}

都市接地層内における熱・水蒸気・ $\mathrm{CO}_{2}$ 輸送を把 握するため, 東京都大田区久が原の住宅地にて長期 観測を行った . フラックスの相関係数を用いてスカ ラー間の輸送効率を調べたところ, 以下のことが明 らかになった。

1 ) 熱と水蒸気の輸送効率比 $r_{w q} / r_{w T}$ は, 朝方大きく 日中にかけて小さくなる傾向がみられる.朝方の不 安定時は, 大きなスケールの渦構造によって混合層 上端からの乾燥空気が連行されることにより，熱に 比へて水蒸気が効率的に輸送されると考えられる．

2 ) 日中の定常と見なせる時間帯において, スカ ラ一間の相関係数を比較したところ，熱・水蒸気・ $\mathrm{CO}_{2}$ の順で輸送効率が落ちていく．スペクトル解 析・ウェーブレット解析を用いて輸送効率に寄与す る渦スケールの特定を行った結果, サーマルやシ アー不安定による組織渦が熱, 水蒸気, $\mathrm{CO}_{2}$ 光れ光 れの輸送を担っている.しかし，これらの輸送イべ ントの各スカラー量に対する効果は同一ではない . 兴の原因として, スカラー間の濃度分布の不均一性 に差異があること，熱がアクティブなスカラー量で
あるのに対し水蒸気・ $\mathrm{CO}_{2}$ が受動的なスカラー量で あること, か理由として挙げられる .

謝辞 : 本研究は文部省科学研究費補助金基盤研究(B) (2) (課題番号 : 12450197), 若手研究(B) (課題番号 : 14750425)，科学技術振興事業団戦略的基礎研究推 進事業 (代表: 神田学) による財政的援助を受けた . また観測場所の提供には, 宗教法人カトリックお告 げのフランシスコ修道会 (代表 : 釘宮禮子樣) に多 大なるこ協力をいただいた．また建物高さの測定に 使用したレーザー距離計は, 東京工業大学国際開発 工学専攻太田教授にお借りした．また東京工業大学 大学院学生の渡邊倫樹さん, 松永和章さんには観測 の準備段階からデー夕解析まで全般に渡り協力を頂 いた .ここに合わせて謝意を表す．

\section{引用文献}

Gao, W. and Li, B. L. (1993) : Wavelet analysis of coherent structures at the atmosphere-forest interface, J. Applied Meteorol., 32, pp. 1717-1725.

Grimmond, C. S. B. and Oke, T. R. (1999) : Aerodynamic properties of urban areas derived from analysis of surface form, J.Appl.Meteor., 38, pp. 1262-1292.

Ho, C-M. and Huerre, P. (1984) : Perturbed Free Shear Layers, Annu. Rev. Fluid Mech.,16, pp. 365424.

Kaimal, J.C. and Finnigan, J.J. (1994) : Atmospheric Boundary Layer Flows, 289pp., Oxford Univ. Press, New York.

神田 学 (1994) : 大気一植生一土猿および水面の 相互作用を考慮した水文気象に関する研究, 東京 工業大学土木工学科学位論文 .

Kanda, M. and Hino, M. (1994) : Organized structures in developing turbulent flow within and above a plant canopy, using a large eddy simulation, Boundary-Layer Meteor., 68, pp. 237-257.

神田学・森脇亮・鈴木 讓· Roth M., Oke, T. R. (2000) : 都市の接地境界層における乱流相似 関数について : 天気, 47, pp. 493-501.

Macdonald, R. W., Griffiths, R. F. and Hall, D. J. (1998) : An improved method for the estimation of surface roughness of obstacle arrays, Atmos. Environ., 32, pp. 1857-1864.

McMillen, R. T. (1988) : An eddy correlation tech- 
nique with extended applicability to non-simple terrain., Boundary-Layer Meteor., 43, pp. 231-245.

森脇 亮・神田 学 (2003) : 都市境界層における 放射・熱・水・ $\mathrm{CO}_{2}$ フラックスの長期連続観測， 水文・水資源学会誌, $16, p p .477-490$.

森脇 亮·神田 学・松永和章・渡邊倫樹(2002): 都市域の陸面パラメーターの算定, 土木学会水工 学論文集, 46, pp. 79-84.

Ohtaki, E. (1985) : On the similarity in atmospheric fluctuation of carbon dioxide, water vapor and temperature over vegetated fields, BoundaryLayer Meteor., 32, pp. 25-37.

Perrier, V., Philipovitch, T., and Basdevant, C. (1995) : Wavelet spectra compared to Fourier spectra, J. Math. Phys., 36, pp. 1506-1519.

Raupach, M. R., Finnigan, J. J., and Brunet, Y. (1996) : Coherent eddies and turbulence in vegetation canopies: The mixing-layer analogy, Boundary-Layer Meteor., 78, pp. 351-382.

Roth, M. and Oke, T. R. (1993) : Turbulent transfer relationships over an urban surface. I: Spectral characteristics: Quart. J. Roy. Meteor. Soc., 119, pp. 1071-1104.

Roth, M. and Oke, T. R. (1995) : Relative efficiencies of turbulent transfer of heat, mass, and momentum over a patchy urban surface: J. Atmos. Sci., 52, pp. 1863-1874.

Roth, M. (2000) : Review of atmospheric turbulence over cities, Quart. J. Royal Meteorol. Soc., 126, pp. 941-990.

渡邊倫樹・森脇 亮・神田 学・松永和章 (2002) : 都 市域におけるコンスタント・フラックス層の存在 条件について，土木学会水工学論文集， 46, pp. 79-84.

Webb, E. K., Pearman, G. I. and Leuning, R. (1980) : Correction of flux measurements for density effects due to heat and water vapour transfer, Quart. J. of Roy. Met. Soc., 106, pp. 85-100.

(受付 : 2002年 9 月10日, 受理 : 2003年 2 月22日) 